УДК 821.163.41.08 Балшић J. $091=163.41 " 14 "$

https://doi.org/10.18485/msc50.2021.2.ch14

Милица Грковић

\title{
ПОСЛАНИЦЕ ЈЕЛЕНЕ БАЛШИЋ
}

Јелена Балшић, кћер кнеза Лазара и кнегиње Милице, рођена је неколико година пре Маричке битке. Одрасла је на двору у Крушевцу, престоници српске кнежевине. У њеној раној младости, цела Србија, а нарочито кнежев двор, били су велика узданица и заштита онима који су изгубили домовину и завичај. Из јужних српских области стизале су избеглице, у нади да ће ту наћи спас испред турске најезде и похара. Духовна елита окупљала се у српским манастирима и на кнежевом двору. Са великим бројем умних и угледних људи дошла је и деспотица Јелена, у монаштву Јефимија, удовица деспота Угљеше, несрећна жена и мајка која је изгубила своја добра, чак и близину гробова најдражих.

На основу казивања Константина Филозофа, Јефимија је на Лазаревом двору нашла не само уточиште него и нови дом, а у деци своје рођаке Милице утеху за своје изгубљено дете. Умна и осетљива, образована и племенита, уткала је један део себе у васпитање мале принцезе Јелене. Верујем да је она имала пресудан утицај на њено формирање и да јој је усадила део онога што је понела из свога завичаја, који је свакако био под великим утицајем Солуна и Цариграда.

Јелена је 1386. године отишла из Србије, постала жена Ђурђа II Страцимировића Балшића „господина све зетске и приморске земље”. Кћер кнеза Лазара је, долазећи у Зету, понела дух свог родног дома и највише образовање које је могла да да̂ тадашња Србија. У Зети, где су били темељи прве српске државе, стекла је нова искуства и нова сазнања. Дах који је допирао са приморја доносио јој је део једног новог света. А у светињама на Скадарском језеру још увек је живео дух њене претходнице Јелене Анжујске.

Ђурђе Страцимировић је умро 1403. године, па је на њу пао тежак терет управљања државом и брига о малолетном престолонаследнику.

${ }^{1}$ Константин Јиречек, Историја Срба, I, Београд, 1952, 321. 
За њу је све то било утолико теже јер јој је пораз на Косову однео оца и многе који су јој у овим судбоносним временима могли бити ослонац. У Србији је сличан терет неизвесности и ратног послекосовског метежа носила њена мајка Милица, уз помоћ блиске јој сроднице монахиње Јефимије.

Највероватније из политичких разлога, удала се поново 1411. за Сандаља Хранића, ${ }^{2}$ великог војводу босанског, оснивача простране области која се од времена његовог наследника почела називати Херцеговина.

Када је остала удовица 1435. године, опхрвана болом због губитка многих блиских, размишљала је да себи подигне вечну кућу у околини Дубровника. Међутим, одлучила је, како сведоче речи забележене у њеном тестаменту, ${ }^{3}$ да буде сахрањена у Зети. Подигла је цркву Благовештења у Горици на Скадарском језеру. Житије Јелене Балшић показује да је ова изузетна жена и владарка припадала многим тадашњим српским областима, те да је од њих усвојила најбоље што су те области имале, дајући им истодобно велики део свога бића. Мало је у средњем веку личности које су у себи носиле толико богато наслеђе, могућност да сагледају раздробљени српски простор и да га на неки начин обједине својим животом и делом.

Васпитавана у најбољој традицији немањићког наслеђа, добро је познавала српско духовно стваралаштво. О томе најбоље сведочи податак да је имала и своју библиотеку.

Неоспорно је да је иза себе оставила доста писаних трагова, али до данашњих дана сачуван је само текст њеног тестамента и посланице коју је писала духовнику Никону Јерусалимцу, сачуване у Горичком зборнику.

Горички зборник се чува у Архиву САНУ. Дуго се о њему ништа није знало. До нас је стигао 1902. године. Купио га је Светозар Томић у Скопљу од неког учитеља. Нема података како је код њега доспео, нити каква је била његова претходна судбина. Тај зборник је био сачињен за Јелену Балшић, као дар њеној задужбини Свете Богородице на скадарској Горици. ${ }^{4}$

Да није било случајног открића, ни до данас не бисмо знали да смо поред владарке Јелене у истој личности имали једну изузетну средњовековну књижевницу, која стоји у истом реду са Јефимијом. Реч је о две сачуване посланице, и трећој, чији се садржај помиње у Никоновом тексту, настале пред крај Јелениног живота, написане свакако између 1440. и $1441 / 2$.

2 Нав. дело, 341.

3 Тестамент Јелене Балшић, Љуба Стојановић, Старе српске повеље и писма, I, Београд - Ср. Карловци, 1929, 349-397.

4 Подаци су добијени у Архиву САНУ. 
Прва посланица није сачувана у целини. Доста је оштећена па се може прочитати само шест редака.

Друга посланица, „отписаније богољубно”, у потпуности је сачувана. Јелена саопштава у њој да је примила писмо од Никона Јерусалимца. Жали што им је виђење било кратко, те није могла дуго да разговара са њим, како би сазнала оно што ју је занимало. Тугује и жели да га види, да чује његове утешне речи. Од њега тражи одговор на питања о киновији, о милостињи и усамљеничком животу.

У трећој посланици, о којој се сазнаје из Никоновог текста, она обавештава Никона о подизању храма Богоматери, саграђеног за место вечног одмора на скадарском острву Горици.

Ове посланице, настале пред крај њеног живота, када је већ сабирала рачуне земаљског живота, припремала дом вечног спокоја, биле су упућене њој блиском бићу, духовнику Никону, од кога је тражила савете и утеху. Дакле, ти текстови нису књижевна фикција, већ стварни дијалог два блиска бића. Истина, облик посланице био је добро познат у старој српској књижевности, али и поред тога што се може очекивати робовање узорима и општим местима, сигурно је да је избор композиције, стилских и језичких елемената Јеленино дело, сачињено по укусу њеног срца и разума. Једноставно речено, Јеленине речи обраћања Никону представљају лирску песму у прози, исказану у молитвеном тону. То је текст у функцији изражавања душе и духа када једно биће, осетљиво и танано, осећа потребу за поткрепљењем душевних сила, да би се лакше поднела мука и невоља свакодневног живота, узнемиреног метежом који је окружује. То је управо универзални став оних људи који имају богат унутрашњи живот. То је потреба за сједињавањем са моћним заштитником на небу. Мада делује као опште место, има аутентичну боју:

Јер помрачише се душевне очи муком и метежом који је у свету. И гле, сада као од некога сна тргнувши се, зажелех твоју светост видети. Посланицу твога рукописања примисмо и великолепно и љубазно од све моје душе изљубисмо, што је лако достижно. И често ову прочитавамо. И веома се утеших и насладих срце моје, а скупа и душу. И тако сматрамо је као неку ризницу веома богату и у њој непроцењивости већма од тисуће тисућа злата и сребра.

И опет се молим твоме преподобију да нам неко олакшање утешења ошаље и прохлади жеђ туге. Јер зна твоје преподобије колике буре и метежи навикоше узбуркавати самовољна срца. 
Висока духовност текста састоји се у евоцирању не само сопствене потребе, него и у осећању себе као честице властитог рода, који очекује заштиту од Христових небеских сила и родитеља и прародитеља подобних светитељима. То је нека врста универзализације заједничког искуства. Утеха је осећање да изнад личне патње и патње рода постоји хармонија. Вероватно је тако Јелена Балшић муке и тегобе земног живота олакшавала очекивањем награде у небеском животу, у који су већ давно упловили њени преци чији су животи описани у биографијама и летописима, и њени ближњи, који су већ ушли у земаљске легенде.

Посланице су писане у ресавском периоду српскословенске писмености, полууставом са елементима брзописа.

Језик је српскословенски, у најбољој традицији средњовековне писмености, научен на двору у Крушевцу од врсних учитеља тога времена, а усавршаван у Зети код великих духовника који су брижно чували српско културно наслеђе, израсло на традицији светосавља.

По дефиницији, он у средњовековној писмености представља „виши стил”, У односу на „нижи стил” докумената писаних народним језиком или списа у којима се преплићу елементи народног и књижевног језика. Укратко речено, језик ових посланица је високо нормирани српскословенски. И мада краткоћа докумената онемогућује потпуни увид у реализацију свих релевантних српскословенских црта, будући да нису присутне све лексеме односно морфолошка средства у којима се иновације очекују, анализа показује да се одступања од норме српске редакције не јављају, те нема наноса из народног говора.

На фонолошком плану, испитивање два кључна питања вокализма датог периода, полугласника и јата, показује, с једне стране, да се полугласник не замењује са $a$, што може упућивати на два закључка: о чувању полугласника у језику Јелене Балшић, или пак о високом познавању етимолошког правописа, док је, с друге стране, потврђен познати и очекивани екавизам српскословенског језика, на основу неколико потврда међу-

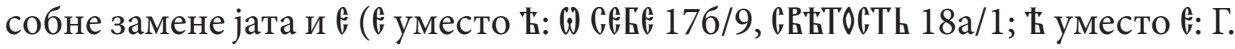

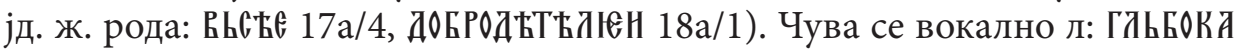
17a/1, СТльПь 2726/11 итд. У консонантизму је запажено доследно спровођење следећих црта: -л на крају речи (РеКьль 16а/7, ЮБНКьль 18а/4),

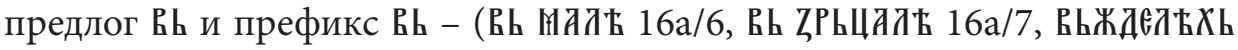
166/4, вькоүПь 16б/9), групе шт и жд (Нен10Шно 166/7, ТысоүШь 17a/8, же-

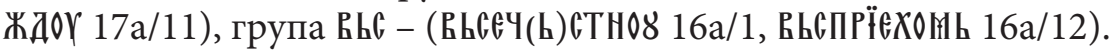

${ }^{5}$ Павле Ивић, О језику у списима светога Саве, Међународни научни скуп, Сава Немањић - Свети Сава, САНУ, Научни скупови VII, Београд, 1979, 169. 
На морфолошком нивоу такође се доследно поштује књижевно-језичка норма, а забележене су наредне српскословенске иновације: наста-

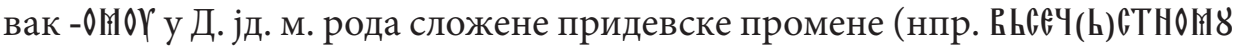
16a/1, A(OY)XOBHOHOY 16a/2), наставак -АГО и Г. јд. исте промене (нпр. \&(В Т(Д)Г0 16а/2), морфологизовани наставци -Æfl h, -€Хh у одговарајућим падежима именичких деклинација (Д. мн. СТР(А)СТенlb 18a/9, Н月 СКРНЖялеХь 2726/6, наставак - flb у 1. л. мн. презента атематских глагола (Hflffl ы $273 \mathrm{a} / 1)$.

На синтаксичко-стилском плану, језик одликују кратке реченице, реторски стил без компликованих конструкција и тешко прозирних обрта, а текст тече континуирано, повезан најчешће везником $\mathrm{H}$, што је у складу са средњовековном књижевном нормом. Тако се од карактеристичних књишких средстава апсолутни датив користи само једанпут (CH九сеноr HH БывшоY 16/8), док се обично реализује његова конкурентна форма, зависна реченица, ближа свакодневном говору. Друга препознатљива књишка црта јесте ретка употреба „члана” єЖе којим се, под грчким утицајем, супстантивизира инфинитив, у резултативном зна-

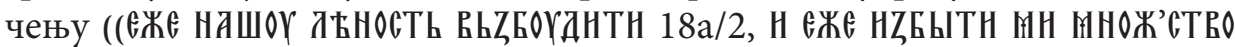

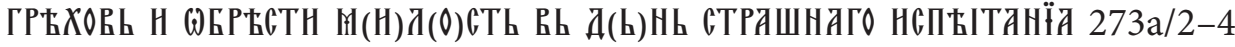

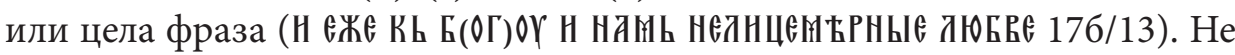
јавља се конструкција датив + инфинитив, као ни калк са грчког, акузатив + инфинитив, нити су запажене компликоване партиципске конструкције. Јелена радо користи инфинитив, али у духу словенске језичке традиције (као допуну разних семантичких класа глагола, објекатску допуну, инфинитив у безличној конструкцији итд.); грчки утицај, који је иначе у ресавском периоду посебно у великој мери обликовао инфинитивне конструкције, није у Јеленином језику дошао до изражаја, изузев једног случаја већ поменутог супстантивизираног инфинитива.

Јасан и питак стил ових посланица свакако је жанровски условљен, одређен епистоларним карактером текста, и суштински одудара од стилског правца „плетенија словес” који иначе цвета у српској књижевности овога периода, као језички и књижевни одговор исихазму, одликујући се, као што је познато, нагомилавањем замршених конструкција, стилских фигура, библијских цитата и метафора, и, у великој мери, синтаксичким грецизмима. Јеленине посланице се, напротив, по једноставности израза, јасности стила и личном тону највише приближавају говорном узору и стилски су ближе писму које је св. Сава писао Спиридону него Посланици кир Исаији Димитрија Кантакузина, обележеној управо стилом „плетенија словес". То је у потпуном складу са правилима епистоларног стила која излажу још најстарији византијски писци. Тако Григорије На- 
зијанзин истиче карактеристике овога стила, међу којима су сажетост и јасноћа, приближавање свакодневном говору, док византијски монах Јосиф Пакендит наглашава да у посланицама треба избегавати китњасти стил, те да стил треба да буде „потпуно чист, без сувишних фигура”... „зато што је писмо - извештај и разговор пријатеља са пријатељем”.

Личном тону Јелениних посланица свакако доприноси често коришћење императива, али је потребно извршити детаљнију и компаративну анализу употребе другог лица једнине и множине у обраћању. Није довољно јасно зашто она неизменично користи друго лице једнине и множине у обраћању Никону, а такође напоредо употребљава прво лице једнине и множине говорећи о себи.

Од именица су у тексту најбројније апстрактне, што даје изузетну духовност изразу, а најчешћи суфикс за грађење тих именица је -ије. На

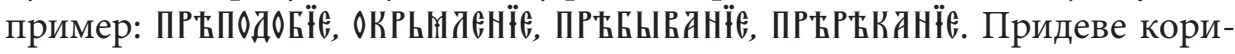
сти у служби атрибута и именског дела предиката. Придеви у служби

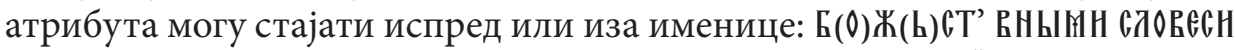

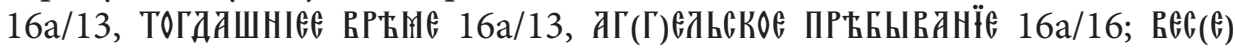

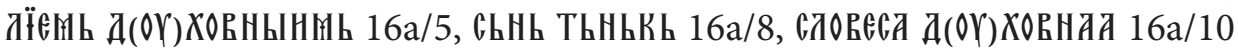
итд. Анализа је показала да је придев испред именице употребљен два пута чешће него придев иза именице. Такође су чешће употребљена два придева у служби атрибута у положају испред именице. У избору атрибута карактеристично је њено опредељивање за два придева која стоје у опозицији дајући тако целом тексту посебну боју. Придев доүХОВьН0,

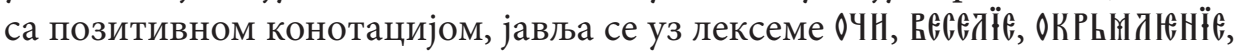
док придев соүюfTьHO, уносећи негативну конотацију, стоји уз лексеме слАвА, жНТїє, којима се означава оно што је везано за профано, у супротности са духовним.

Цитати, који одликују средњовековна књижевна дела, овде нису дошли до изражаја. Једино се у тексту позива на мисли које „неки” говоре

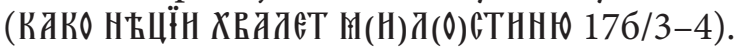

У тексту се запажа низ општих места, „топоса”, који се у делима средњовековне књижевности често јављају, представљајући, још од античког времена, важну тему. Тако је изражена чежња за духовним сједињавањем и близином са оним ко је далеко, а духу потребан. Умножавање талената као опште место среће се и овде и представља величање духовног прегнућа, слично као и у многим делима средњовековне литературе. Истицање смерности као духовног идеала истакнуто је епите-

${ }^{6}$ Ђорђе Трифуновић, Азбучник српских средњовековних књижевних појмова, Београд, 1990, 265. 


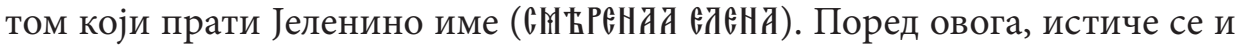
смерност монаха Никона коме Јелена указује на то да је уплашена да због његове велике смерности може језик затворити.

Наравно, за подробнији увид у језик и стил ових посланица, као и епистоларног израза у целини, неопходна су шира истраживања већег броја текстова из средњовековне литературе и писмености уопште, језичкостилска испитивања која би својим резултатима омогућила дефинисање стилских карактеристика посебних књижевних жанрова, а затим компаративном анализом одредила карактеристичне црте сваког стила понаособ. Тек у том светлу биће могуће у потпуности разумети и одредити и вредност и место посланица Јелене Балшић у старој српској књИжевности. 